\title{
Program Pendidikan Anti Korupsi Pada Siswa Sekolah MENENGAH ATAS (SMA)
}

\section{${ }^{1}$ Inayati Nuraini Dwiputri, ${ }^{2}$ Rizky Dwi Putri, ${ }^{3}$ Sri Umi Mintarti, ${ }^{4}$ Dian Rachmawati, ${ }^{5}$ Rizza Megasari}

\author{
1,2,3,4,5 Universitas Negeri Malang \\ email: ${ }^{1}$ inayati.dwiputri.fe@um.ac.id, ${ }^{2}$ rizky.dwi.fe@um.ac.id, ${ }^{3}$ sri.umi.fe@um.ac.id, \\ ${ }^{4}$ dian.rachmawati.fe@um.ac.id, ${ }^{5}$ rizza.megasari.fe@um.ac.id
}

\begin{abstract}
Community Service Activities in the form of Anti-Corruption Education for High School Students (SMA) aims to: (1) Create young people who have democratic perspectives, attitudes and behaviors for the benefit of society, nation and state, have integrity, and are anti-corruption. (2) Bringing up a new generation that prioritizes services to the Indonesian people in general (3) Encouraging the birth of young political cadres who are intelligent, with integrity and anti-corruption at the level of high school students in particular. These goals can be achieved by using three methods, namely: training for high school students, simulations and anticorruption educational games, and project based learning for the anti-corruption challenge. The results of anti-corruption education program activities in high school students include being able to provide understanding and motivation to students regarding anti-corruption attitudes through the provision of material and screening of anti-corruption films. This program is able to hone students to think critically and provide hands-on experience of corrupt practices through simulating anticorruption games and working on project-based learning by creating posters in groups and presenting them.
\end{abstract}

Keywords: Anti-Corruption, integrity, Project Based Learning

\begin{abstract}
Abstrak. Kegiatan Pengabdian kepada masyarakat berupa Pendidikan Anti Korupsi pada Siswa Sekolah Menengah Atas (SMA) ini bertujuan untuk:(1) Menciptakan generasi muda yang memiliki perspektif, sikap dan perilaku yang demokratis untuk kepentingan masyarakat, bangsa dan negara, memiliki integritas,dan anti korupsi.(2) Memunculkan generasi baru yang mengedepankan pelayanan kepada masyarakat Indonesia pada umumnya.(3) Mendorong lahirnya kader politik muda yang cerdas, berintegritas, dan anti korupsi di tingkat siswa SMA khususnya. Tujuan tersebut dapat dicapai dengan menggunakan tiga metode, yaitu: pelatihan kepada siswa-siswi SMA, simulasi dan permainan pendidikan anti korupsi, dan project based learning untuk challenge antikorupsi. Hasil dari kegiatan program pendidikan anti korupsi pada Siswa SMA antara lain adalah mampu memberikan pemahaman dan motivasi kepada siswa mengenai sikap anti korupsi melalui pemberian materi dan penayangan film anti korupsi. Program ini mampu mengasah siswa untuk berfikir kritis dan memberikan pengalaman langsung praktik korupsi melalui simulasi permainan anti korupsi dan pengerjaan project based learning dengan membuat poster secara berkelompok dan mempresentasikannya.
\end{abstract}

Kata Kunci: Anti Korupsi, integritas, Project Based Learning.

\section{Pendahuluan}

Pembelajaran masa kini terus mengalami inovasi, sesuai dengan dinamisnya tuntutan kompetensi abad 21. Perubahan paradigma cara belajar siswa yang berbeda dibandingkan masa sebelumnya. Banyak pekerjaan rumah 
yang harus diselesaikan guru di sekolah dengan perubahan kurikulum dan cara belajar siswa.

Korupsi di negara ini sudah menyeluruh dibidang- bidang kehidupan sosial,bahkan rantai korupsi telah mengakar dari tingkat pusat hingga tingkat desa. Korupsi telah menjangkiti tatanan birokrasi dari atas sampai bawah, DPR, dunia perbankan, dunia pendidikan, dan lembaga-lembaga lainnya. Praktek korupsi ibarat seperti penyakit yang sulit untuk disembuhkan, bahkan menjadi kebiasaan dalam kehidupan sehari-hari.

Pemberantasan korupsi di Indonesia menjadi tanggungjawab semua masyarakat bukan hanya tanggungjawab aparat penegak hukum. Dalam pemberantasan korupsi, ada tiga aspek yang dilakukan. Pertama, penindakan, kedua, pencegahan, dan ketiga, pendidikan. Ketiga aspek tersebut wajib berjalan selaras untuk meraih hasil yang optimal. Keselarasan ketiga aspek itu harus dilandasi oleh komitmen dan kesadaran yang tulus dari masyarakat di negara ini.

Pengertian korupsi Menurut UU No. 20 Tahun 2001 Tentang Pemberantasan Tindak Pidana Korupsi adalah tindakan melawan hukum dengan maksud memperkaya diri sendiri, orang lain, atau korupsi yang berakibat merugikan negara atau perekonomian negara. Oleh karena itu, memerlukan upaya luar biasa untuk memberantasnya.

Upaya pemberantasan korupsi tidak akan berhasil jika hanya dilakukan oleh pemerintah saja tanpa melibatkan peran serta masyarakat. Oleh karena itu, perlu melibatkan masyarakat sebagai salah satu bagian penting yang diharapkan dapat terlibat aktif dalam upaya pemberantasan dan pencegahan korupsi di Indonesia. Upaya pencegahan korupsi dapat ditanamkan sejak dini, sejak anak masih duduk di bangku SD, SMP, maupun SMA.

Jika berbicara masalah pendidikan, pasti berkaitan dengan persoalan mendasar dan berhubungan dengan manusia. Pendidikan bukan sekadar aktivitas transfer ilmu, namun juga harus mampu dalam mengembangkan dan mengeksplorasi potensi diri dan kecerdasan emosi para peserta didik.

Secara luas, pendidikan merupakan pengaruh lingkungan terhadap individu untuk menghasilkan perubahan-perubahan yang tetap dalam kebiasaan perilaku, pikiran dan sikapnya. Untuk pengertian secara umum menurut UU No. 20 Tahun 2003 Tentang Sistem Pendidikan Nasional Pasal 1 Ayat 1 menyatakan bahwa pendidikan adalah usaha sadar dan terencana untuk mewujudkan suasana belajar dan proses pembelajaran agar peserta didik secara aktif mengembangkan.

Potensi dirinya untuk memiliki kekuatan spiritual keagamaan, pengendalian diri, kepribadian, kecerdasan, akhlak mulia, serta keterampilan yang diperlukan dirinya, masyarakat, bangsa, dan negara. Berdasarkan UU tersebut, idealnya siswa memiliki sifat yang berakhlak mulia dan bermartabat untuk menjadi manusia yang sehat dan bersih dari korupsi.

\section{Metode}

Metode yang digunakan dalam pelaksanaan program pendidikan anti korupsi ini adalah:

2.1 Metode pelatihan kepada siswa-siswi SMA Laboratorium UM.

Metode pelatihan ini dilakukan dengan ceramah dan diskusi tanya jawab mengenai materi anti korupsi, dampak korupsi dan tindakan yang dapat dilakukan oleh siswa-siswi untuk 
menghindari dan menghentikan praktek korupsi yang ada di sekitar siswa-siswi. Pelatihan dan penyampaian materi juga dilakukan dengan menyajikan video pewujudan sikap anti korupsi.

2.2 Simulasi dan permainan pendidikan anti korupsi .

Simulasi praktik anti korupsi simulasi dilakukan dengan pengalaman langsung melaksanakan permainan dan memerankan peran sebagai aktor-aktor dalam politik dan ekonomi yang dapat membuat kebijakan dan melaksanakan kegiatan ekonomi. Permainan ini dimaksudkan untuk menyajikan situasi yang mirip dengan kenyataan asli di lapangan tentang korupsi dan dampaknya terhadap masyarakat.

Permainannya menggunakan kartu peran, melibatkan 6 siswa yang kesemuanya mempunyai peran serta misi yang harus dipecahkan untuk menemukan siapa yang melakukan korupsi dalam suatu proyek yang diberikan.

\subsection{Project Based Learning} untuk challenge antikorupsi.

Metode project based learning membagi siswa-siswi ke dalam kelompok-kelompok kecil. Tugas dari setiap kelompok adalah mendiskusikan cara mencegah korupsi kemudian menuangkannya dalam lukisan poster. Poster memuat gambaran singkat dan ajakan untuk mencegah korupsi. Di akhir sesi, masing-masing kelompok mempresentasikan hasil poster.

Kegiatan pengabdian kepada masyarakat ini tercapai dari adanya kerjasama dengan mitra. Mitra dalam hal ini adalah SMA laboratorium UM, sedangkan subjek yang diberikan pelatihan adalah siswa-siswi kelas XII IPA dan IPS yang berjumlah 62 orang.

\section{Hasil dan Pembahasan}

Target dalam Program Pendidikan Anti Korupsi ini adalah siswa-siswi SMA Laboratorium UM Kota Malang. Pelaksanaan kegiatan ini dengan metode pelatihan kepada siswasiswi SMA labrotatorium UM, Simulasi dan Permainan Pendidikan Anti Korupsi, dan Project Based Learning untuk challenge anti korupsi.

Metode pelatihan terlaksana dengan kegiatan sosialisi anti korupsi dan penayangan video anti korupsi. Kegiatan ini merupakan wujud pemberian pelatihan pendidikan anti korupsi kepada siswa-siswi SMA Lab UM. Kegiatan ini dilakukan dengan pemberian materi atau seminar dengan judul "Perekonomian Korup di Indonesia".

Hal-hal yang terdapat dalam materi ini antara lain, definisi korupsi menurut UU dan para ahli, faktor-faktor penyebab korupsi, gambaran terhadap korupsi di Indonesia, distribusi terpidana korupsi menurut jenis pekerjaannya, dan dampak yang ditimbulkan akibat adanya korupsi.

Pada saat sesi pemaparan materi ini, siswa-siswi antusias mengikuti. Beberapa siswa memberikan tanggapan mengenai materi yang dijelaskan dengan fenomena yang mereka ketahui. Siswa-siswi juga aktif dalam sesi tanya jawab. Siswa juga diberikan kesempatan untuk menanggapi pendapat dari temannya.

Siswa juga diajak untuk melihat tayangan film pendek didampingi oleh tim pengabdian. Terdapat dua film pendek yang ditayangkan. Film pertama mengisahkan mengenai sikap kejujuran yang berani dilakukan oleh seorang anak kecil dan temannya.

Video kedua mengenai potret pekerja yang jujur dan tidak mau menerima suap meski dihadapkan pada keadaan yang sulit jika tidak menerimanya. Video yang dibuat dan dipublikasikan dalam web resmi Pendidikan Anti Korupsi KPK aclc.kpk.go.id. Siswa menangkap apa 
yang harusnya ditanamkan pada diri tentang nilai-nilai antikorupsi yang disampaikan oleh film. Disampikn juga 9 nilai anti korupsi yang harus ditanamkan siswa pada diri sendiri yaitu jujur, peduli, mandiri, disiplin, tanggung jawab, kerja keras, sederhana, berani, dan adil (Ju-Pe- Man-Di- TangKer- Se-Be-Dil).

Dalam program pendidikan anti korupsi, siswa mendapatkan simulasi praktik dengan permainan anti korupsi. Nama permainan ini adalah The Suspect adalah board game dengan 6 orang pemain yang akna mewakili 6 profesi berbeda. Masing-masing orang memainkan salah satu dari 2 peran, yaitu orang baik atau oknum. Tugas kartu baik adalah melancarkan proyek. Sedangkan kartu oknum tugasnya menggagalkan proyek dan tidak boleh tertangkap.

Pemain menentukan suatu proyek akan berhasil atau gagal sesuai peran masing-masing. Pemain dibantu dengan kartu profesi untuk menentukan jalannya permainan. Profesi tersebut adalah tokoh masyarakat, politis, jaksa, polisi, peneliti ahli, dan gubernur. Komponen permainan ini adalah kartu karakter, kartu profesi, kartu proyek, kartu SDM, dan token.

Permainannya ada 2 fase, yaitu fase seleksi dan fase penilaian. Proyek dinyatakan sukses apabila kartu SDM tidak ada yang berjenis ill will atau pemain yang mendapatkan token intai terbanyak benar adalah oknum. Namun, jika pemain berkarakter oknum mendapat token intai lebih sedikit, maka proyek dinyatakan gagal.Siswa terlihat sangat antusias dalam mengikuti dan memainkan permainan ini hingga simulasi dilakukan dalam beberapa ronde/putaran permainan. Project based learning untuk challenge anti korupsi merupakan tugas akhir yang diberikan kepada siswa yang berkumpul dalam beberapa kelompok kecil untuk melakukan diskusi dan membuat poster ajakan tindakan yang anti korupsi.

Hasil dalam projek kelompok ini adalah poster yang berisi beragam pesan didalamnya. Baik slogan maupun gambar mengenai perilaku anti korupsi dan ajakan untuk menolak korupsi, bahkan mencegahnya. Terdapat sepuluh poster dari dua kelas. Kemudian masing-masing kelas dipilih satu poster terbaik dan diberikan reward untuk tim terbaik. Penilaian poster berdasarkan kombinasi gambar dan pesan yang tertuang dalam poster.

Evaluasi dalam kegiatan ini tercermin dari nilai Post Test dan PreTest siswa-siswi SMA Laboratorium UM, terlihat kenaikan yang cukup signifikan dari total nilai saat pre test (saat mereka belum menerima materi apapun) dibandingkan dengan nilai post test (setelah materi, game, dan membuat poster). Total nilai saat pre test untuk keseluruhan adalah 3.280, sedangkan nilai post test adalah 4.790. Terdapat kenaikan 46,03\% mengenai pemahaman siswa mengenai anti Korupsi.

Pemahamam siswa juga berkembang, yang ditunjukkan dari jawaban pretest terkait pengertian korupsi yang diketahui siswa pada awalnya hanya sebatas penyelewengan uang/dana yang bukan miliknya dan beberapa yang menjawab penyalahgunaan wewenang yang dimiliki. Pemahaman ini kemudian berkembang lebih luas bahkan tidak hanya uang dan wewenang, tetapi juga kesalahan diri seperti tidak jujur, tidak disiplin, melanggar aturan sekolah/lalu lintas/marka jalan dll yang merugikan orang lain merupakan bentuk tindakan yang tidak sesuai dengan nilai-nilai anti korupsi sekalipun tidak dilakukan oleh orang yang memiliki jabatan atau wewenang tertentu.

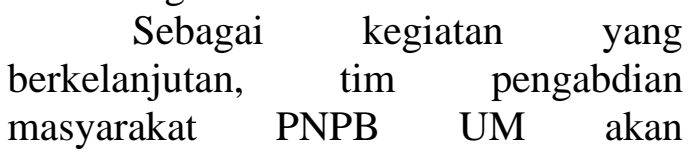


melaksanakan monev internal dan monev eksternal. Kegiatan lain yang dilakukan adalah merilis publikasi jurnal ilmiah berISSN, publikasi video yang akan diupload di kanal youtube, serta implementasi program pendidikan anti korupsi berbasis online. Diharapkan materi pendidikan anti korupsi ini dapat disampaikan pada khalayak umum.

\section{Kesimpulan dan Saran}

Kesimpulan dalam program pendidikan anti korupsi ini adalah pemberian pelatihan, simulasi melalui permainan anti korupsi, dan pemberian challenge melalui project based learning dapat menciptakan generasi muda yang memiliki perspektif, sikap dan perilaku yang demokratis untuk kepentingan masyarakat, bangsa dan negara, memiliki integritas,dan anti korupsi.

Memunculkan generasi baru yang mengedepankan pelayanan kepada masyarakat Indonesia pada umumnya. Dan Mendorong lahirnya kader politik muda yang cerdas, berintegritas, dan anti korupsi di tingkat siswa SMA khususnya.

Hal ini dibuktikan dengan keikutsertaan seluruh siswa-siswi dalam setiap kegiatan. Antusias bertanya dan menanggapi dari siswa-siswi. Hasil poster setiap kelompok dalam project challeng. Dan peningkatan pemahaman sikap anti korupsi dari nilai pre test dan post test yang diberikan.

Saran yang dapat diberikan penulis kepada institusi pendidikan adalah supaya memberikan pengajaran yang disertai pengalaman langsung baik dengan diberikan simulasi atau diberikan project based learning. Adapun saran bagi pembaca adalah dijadikan referensi sumber ajar, penelitian, atau pelaksanaan program pengabdian kepada masyarakat lainnya.

\section{DAFTAR PUSTAKA}

Manurung, R.T. 2012. Pendidikan Anti Korupsi sebagai Satuan Pembelajaran Berkarakter dan Humanistik. Jurnal Sosioteknologi, 11(27), 234-236.

UU No. 20 Tahun 2001 Tentang Pemberantasan Tindak Pidana Korupsi. KPK (online), (http://kpk.go.id), diakses 14 September 2019.

UU No. 20 Tahun 2003 Tentang Sistem Pendidikan Nasional. Ristekdikti (online), (https://kelembagaan.ristekdikti.go.i d), diakses 14 September 2019. 